\title{
Opportunities and Challenges of Mobile Learning That University Students Encounter in the UAE
}

\author{
Ghadah Al Murshidi ${ }^{1}$ \\ ${ }^{1}$ Department of Curriculum and Instruction, College of Education, United Arab Emirates University, UAE \\ Correspondence: Ghadah Al Murshidi, Department of Curriculum and Instruction, College of Education, United \\ Arab Emirates University, UAE.
}

Received: November 5, 2017

Accepted: November 21, 2017

Online Published: December 4, 2017

doi:10.5430/irhe.v2n4p18

URL: https://doi.org/10.5430/irhe.v2n4p18

\begin{abstract}
This study presents preliminary results based on a survey administrated to a sample of 400 students enrolled in undergraduate courses offered at a Higher Education Institution in the United Arab Emirates (UAE). The paper examines opportunities and challenges university students face when instructors introduce "structured" mobile learning in higher education. In part, this article presents qualitative findings of the larger study involving a subset of the sample, to gain in-depth data. Closed-ended and open-ended questions probed students' experiences and perceptions about the use of mobile devices in academic work. Findings reported in this paper focus on students' perceptions on opportunities and challenges. The analysis revealed that a majority of students used iPads, cell phones, and laptop computers to study anytime and anywhere. Respondents reported that these technological devices enabled students to meet deadlines faster than students without mobile devices. In addition, students indicated that they faced difficulties accessing Internet networks in most places. This phenomenon has afflicted students' productivity and efficiency levels, since most academic work required Web searches and Internet connectivity. Nevertheless, students benefited a great deal in using such mobile technological devices and admitted that the benefits outweighed the challenges they encountered.
\end{abstract}

Keywords: mobile learning, mobile devices, digital technologies, internet connectivity

\section{Introduction}

In the past decade, a quiet revolution has taken place in the global demand for mobile devices (Quillen, 2011). During this period, mobile computing devices have become as ubiquitous as to be seemingly omnipresent in classroom settings. At first, a few students brought their laptop computers to class. Soon computers were followed by Personal Digital Assistants (PDAs), and then cell phones. Since then, these devices have re-emerged on the market with new applications and gadgetry, as is evident from cell phones with cameras and smartphones, for example. Currently, there are so many different digital mobile technologies available that it becomes difficult for the typical classroom teacher to identify them, much less determine or fathom their potential uses.

The rapid spread of digital technologies is noticeable everywhere and has affected every age group, race, and country (Al-Emran, Elsherif, \& Shaalan, 2016; Santos \& Bocheco, 2014). Students are coming to classrooms armed with many of the latest mobile devices, including notebook computers, smartphones, and recording pens like the Livescribe. These devices allow students to photograph, record (both audio and video), transmit, receive, and retrieve information during class sessions. Faculty members are unsure or not prepared for the introduction of these devices into the classroom. They are unsure of their capabilities and potential, yet they do not know how to deal with them from a classroom management and policy viewpoint: shut them off or allow and embrace the mobility and connectivity of mobile devices? Noticeably, this predicament poses a dilemma!

Overall, the spread and integration of mobile technologies at work, schools, universities, and institutions of higher learning are on the rise. The nagging question is: Do these devices do anything to learning? In fact, the surge in the spread and integration of mobile technologies in education has left policymakers and regulators behind the curve (Knezek \& Khaddage, 2012). The proliferation of digital devices is inevitable and yet integration of mobile applications, mobile social networking platforms, and other mobile applications has become part of social life and is slowly overtaking teaching and learning. What can instructors do with these developments? What pedagogies should 
instructors use to integrate digital mobile media in education? These questions are overwhelming to some educators, and the present study searched for answers.

Scholars admit that the rapid spread of mobile technologies has empowered informal learning everywhere. The proliferation has inspired scholars everywhere to investigate new methods, models, and novel ways. Specifically, the quest is in terms of (a) the extent of use (Khaddage, Müller, \& Flintoff, 2016); (b) the benefits of encouraging mobile technologies in classrooms (Hamm, Saltsman, Baldridge, \& Perkins, 2013); and (c) establishing whether mobile learning can outpace current face-to-face teaching styles and learning applications (Bencheva, 2010; Khaddage, Christensen, Lai, Knezek, Norris, \& Soloway, 2015).

Many questions arise: Should administrators and other university stakeholders support these new technologies with budgetary resources and innovative research? What opportunities and challenges do students encounter as they transition from face-to-face to mobile learning? These questions need speedy answers, and therefore the present study is timely and necessary. It is necessary to analyze critically the uses of mobile devices in teaching and learning, and the opinions and perceptions of students should shed light on this dilemma. The present study attempts to take on this task.

Scholars have observed that mobile learning grew from a minor research interest to what has now become a set of significant projects in schools, workplaces, museums, cities, and even rural areas around the world (Velev, 2014). However, there is no consensus among scholars about the benefits that result from the use of mobile technologies over face-to-face teaching and learning in higher education. Previous research studies have established that the rapid dissemination of information fuels the current knowledge economy, and mobile technologies are part of this rapid progress (Apulu, Latham, \& Moreton, 2011; Ongori, \& Migiro, 2010). Variations exist in the level of diffusion and spread of the new technologies. The levels of adoption have not been uniform throughout, and such divergences are noticeable between academia and industry, and between higher education and private social uses. Equally, the learning curve varies among demographic groups and populations (BrckaLorenz, Haeger, Nailos, \& Rabourn, 2013). These developments have significantly affected the ways users interact with information on a daily basis. The present study examines these issues in the literature and suggests implications for future creative uses of mobile devices in higher education, as well as the ways in which technological innovations can stimulate university research and discovery.

One area that interests scholars recently is online teaching and e-learning or mobile learning (m-learning). The presence of mobile devices in schools has promoted and instigated distance learning exponentially, and college-age students claim to be the digital commons of the future. This new generation prefers mobile learning instead of relying on traditional face-to-face teaching and learning (Bencheva, 2010). Essentially, e-learning occurs when the learner and teacher are not at a fixed or predetermined location such as the classroom. Alternatively, it is learning that happens when the learner takes advantage of the learning opportunities offered by mobile technologies such as information retrieval capabilities when at a distance. For example, mobile device features with Wi-Fi capabilities allow for on-demand access to information. Access to classroom activities and information on mobile devices provides a continuum for learning inside and outside the classroom (Sanderson \& Croft, 2012). Scholars believe that e-learning is different from other types of learning in the sense that it has the mobile aspects of distance learning that make learning stand apart from other types of face-to-face or tactile learning, specifically in the modes of designing learning experiences that exploit the opportunities that mobility can offer students (Sanderson \& Croft, 2012).

The term "mobile learning" (m-learning) comprises different meanings in disparate communities who reference this act of learning as subset of e-learning, or educational technology and distance education that focuses on learning and teaching with mobile devices. Mobile learning also incorporates a number of learning activities conducted on the Internet, of which mobile learning is one part (Deegan, \& Rothwell, 2010; El-Hussein, \& Cronje, 2010). Therefore, $\mathrm{m}$-learning focuses on the mobility of the learner, interacting with portable technologies, and the type of learning that reflects how society and its institutions can accommodate and support an increasingly mobile population (Attewell, \& Savill-Smith, 2004; Singh, 2010). In sum, m-learning has dealt with mobility from a number of dimensions: mobility of technology, mobility of learners, mobility of educators, and mobility of learning (Al-Emran, 2016). The assumption in this equation is that mobile devices have features and functionality for supporting learning and learners (Chen, Chang, \& Wang, 2008).

The present study examines the dimensions of mobile learning and whether the use of mobile devices facilitates students' academic work or contrarily whether mobile devices are responsible for insolence among some students in different circumstances - only to make classroom management a nightmare for instructors. So do mobile devices add value completely to the educational enterprise? How do processes of e-learning compare to face-to-face teaching and learning? Or even with other computer-assisted teaching? The overall assumption of this study is that students in the 21 st century need a stronger technological foundation from an early age in order to succeed in higher education, to be 
ultimately effective and productive in society. To meet the demands of the emerging global economy, universities must prepare college students with the competencies that allow them to navigate institutions and industries of the 21 st century (Ally, 2009; Selwyn, 2007).

For this reason, universities must integrate technology into university content areas as well as online platforms. Instructors must have a positive approach toward using technology and adequate professional skills that advance success, and equally, develop the pedagogy for it. When technology is used appropriately, it can be a perfect addition to the educational system (Roden, 2011). The present case study examines these propositions among UAE university students.

In this study, the researcher measures learning in terms of the generation of e-learning activities using mobile technologies. A possible outcome is to identify and establish a relationship between the use of iPads, laptop computers, and other mobiles in the instructional process. Equally, it is valuable to find out what students think about mobile devices in terms of facilitating their learning or in complementing their academic experience in higher education. The next steps will be to determine the level of technology used in different universities and examine the benefits and challenges college students encounter.

First, this paper outlines the dimensions of mobile learning in the context of higher education. Second, the researcher presents survey data and analysis of students' responses to open-ended and close-ended questions to determine which factors account for the benefits or disadvantages of use of mobile technologies in higher education. The aim of this analysis is to scrutinize the variability of factors including the student academic skills, definitions of mobile learning, benefits, challenges, disadvantages, and the diverse uses that each student brings to the mobile technology. Finally, the article concludes with a discussion of the results, suggests incipient implications, and proposes areas of further study.

\section{The Context of Mobile Learning in Higher Education}

In the UAE, universities are steadily introducing new technological devices in teaching and learning, and slowly doing away with the old, low-tech audiovisual technologies. Apparently, few universities can ignore the digital technological imperatives of the $21^{\text {st }}$ century. However, there is an earnest quest and thirst for theory to inform and support the new developments (Sharples, Taylor, \& Vavoula, 2005). Currently, technology has greatly influenced the education system in the UAE in large measure. The days of overhead projectors are dwindling, rearview projectors and Da-Lite pull-down screens are disappearing, and paperless dictates are becoming widespread. These developments have become the precursor of new ways of e-learning and teaching, and of more sophisticated ways that are yet to come (Selwyn, 2007).

In sum, e-learning arises from any dissemination of information of educational knowledge over the Internet. Even though e-learning is fueled by what goes on the Internet, we distinguish the technological uses from m-learning as a subset of technology-based education. The term m-learning (or mobile learning) has different meanings for different communities. This type of learning refers to subsets of e-learning, educational technology, and distance education that cuts across contexts and with various mobile devices.

Mobile learning has different meanings and is sometimes referenced in terms such as m-learning, u-learning (ubiquitous learning), personalized learning, learning while mobile, anytime/anywhere learning, or hand-held learning. Simply put: mobile learning is "any sort of learning that happens when the learner is not at a fixed, confined, predetermined location, or learning that happens when the learner takes advantage of the learning opportunities offered by mobile technologies" (MOBIlearn, 2003). In other words, learners can learn with mobile devices anywhere and at anytime (Crescente \& Lee, 2011), which means using devices that enable access to learning information without posing any restriction on time or location.

The term mobile learning lacks specificity and therefore is subject to debate. The term refers to the ability of mobile learning that encompasses both formal learning within the classroom, and informal or formal learning outside the classroom, across myriad devices, in a variety of physical and temporal arenas. Interaction with mobile devices is only one part of the puzzle; of key importance in this discussion of mobile learning are the interactions that mobile devices support and the ways in which these supports lead to learning (Hockly, 2013).

Concurrently, many educational institutions use technology to teach students in a variety of ways. For example, in the past year we have observed the introduction of social networking in the classroom, where students, for example, use iPads for online research, to define words, listen to music of historical periods, and more (Murthy, 2008). In lower grades, teachers and students are exploring the educational uses of cell phones, though highly controversial. 


\section{Literature Review and Theoretical Assumptions}

The influx of smart phones in most college classrooms is affecting instruction in a way that no educator could have anticipated (Quillen, 2011). When the iPad was launched in 2010, numerous devices emerged, and, in tandem, mobile learning has expanded rather than decreased. The new digital technological breakthroughs seem to be opening many doors to new devices, and the combination of technologies continues to get more complex as the years go by (Apple, 2010). New applications and new devices provide many opportunities to get an education and to expand the knowledge of students. However, students' responsiveness to mobile technologies is one of the few areas studies have addressed, but since the iPad was launched in 2010, numerous projects and studies have emerged worldwide within myriad settings (Gasparini, 2013).

\subsection{Perspectives on Theory}

Past studies have identified areas where students face challenges, as well as the lack of accessibility to certain platforms or formats of files, or lack of storage capacities that most mobile devices provide. The connectivity of network(s) is also lacking in some places that can affect students negatively (e.g., not being able to view online files that require a network connection).

In addition, there is a constant yearning for a conceptual framework for mobile learning applications that will provide systematic support for mobile lifelong learning (Murthy, 2008; Sharples, Taylor, \& Vavoula, 2010). Such a framework encompasses four perspectives: (1) generic mobile environment issues, (2) learning contexts, (3) learning experiences, and (4) learning objectives (Murthy, 2008). Murthy believes there is also need for identifying the crucial factors and design requirements for mobile learning environments.

The growing amount of research concerned with applying mobile technology to lifelong learning, issues of cost, adaptability, and scalability are among motivations most often cited for using mobile technologies in learning (Nordin, Embi, \& Yunus, 2010). However, researchers must remember that the use of technology must be driven by pedagogical considerations rather than financial, logistical, or technical reasons (Ozdamli, 2012). Ozdamli identifies four key aspects for a pedagogical framework for mobile learning: (a) integration of tools, (b) pedagogical approaches, (c) assessment techniques, and (d) teacher training.

Abu-Al-Aish and Love (2013) proposed a model that identifies the factors influencing the acceptance of m-learning in higher education based on the unified theory of acceptance and use of technology (UTAUT). They concluded that performance expectancy, effort expectancy, lecturers' influence, quality of service, and personal innovativeness are significant determinants of the behavioral intention to use m-learning. The Abu-Al-Aish and Love study used gender, major, age, experience of mobile devices, usage of m-learning, frequency of using $\mathrm{m}$-services for learning, and m-learning knowledge in order to pinpoint the characteristics of participants.

Alternatively, Sharples, Taylor, and Vavoula (2005) proposed a framework (commonly referred as CHAT) as an avenue to theorize mobile learning. This framework was adapted from Engestrom's expansive activity model (see Fig. 1 ), which reflected the learning process that occurs outside classrooms.

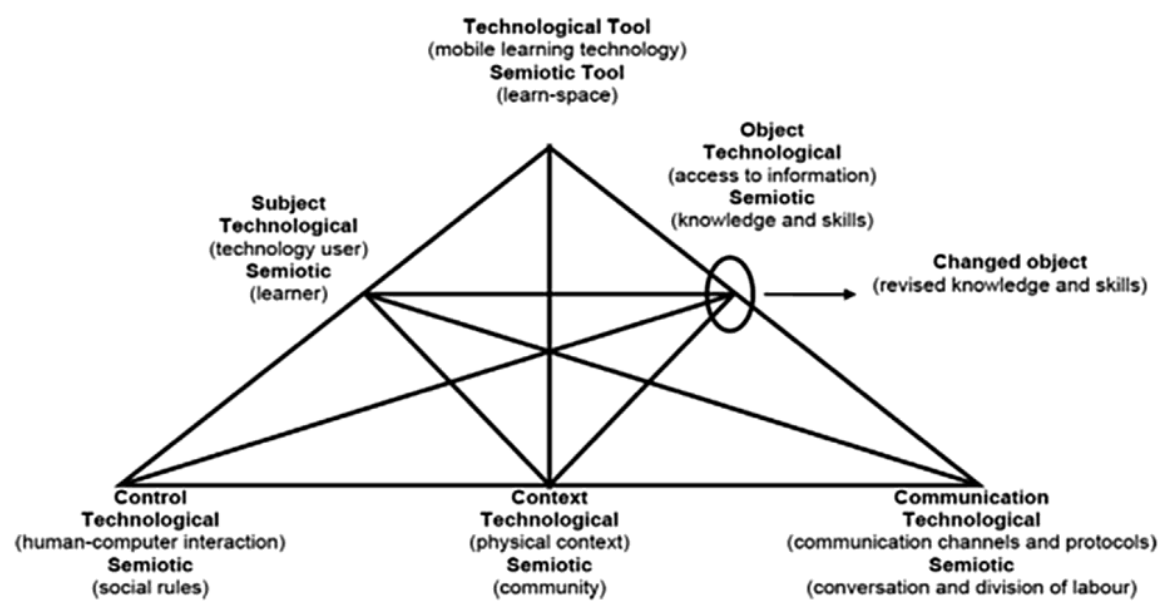

Figure 1. A framework for analyzing M-learning (Sharples et al., 2005) 
The envisioned framework suggested that learning occurred as a socio-cultural system where educators and technology are the controls, while Context is the communities of actors (people and technology), and Communication technology adaption drives the use of technology in m-learning.

On the other hand, Liaw, Hatala, \& Huang, (2010) proposed a mobile learning framework that is adapted from Sharples's framework. They proposed a framework based on the activity theory. This time the focus was on the mobility of learning. Liaw and colleagues argued how new technologies can support knowledge management, accessibility, exchangeability, and delivery of both knowledge and learning materials.

However, according to Sharples et al. (2005), the implementation of educational technology, as they saw it, should consist of three parts: the learner, the educator, and the technology itself. The assumption here is that m-learning as an educational technology will involve both the learners and educators to take part in its implementation strategy (i.e., in order for learning to occur, we need both actors). This point is well taken because it means it would be futile to study or focus on the learners (students) and leave out educators' (faculty members') attitudes toward the use of such technology in the study. In the present study, I analyzed the opinions of students and polled some teachers to validate the opinions expressed by students about their use of mobile devices (e.g., iPads) and the challenges they encountered.

\subsection{Pedagogical Issues}

In an attempt to find viable pedagogical approaches, researchers in language learning have explored language teaching by using many mobile devices, such as cell phones; pocket PCs, and Apple iPhones (Kukulska-Hulme, 2009). These researchers often worry about features that capitalize on Wi-Fi access, Internet browsers, or text input (Liu, Huang, Salomaa, \& Ma, 2008). In addition, some of these researchers have found that embracing the mobility and connectivity of mobile devices may lead to innovation in language use or vocabulary growth or enrichment for pupils across different platforms and environments.

For example, it has been shown that cell phones are increasingly used for improving knowledge of vocabulary, grammar, listening, and speaking, in both formal and informal settings (Miangah, \& Nezarat, 2012). Furthermore, the use of mobile tools to support content with social communication features are known to empower teachers and students to participate in more cooperative learning environments (Kim, Rueckert, Kim, \& Seo, 2013).

\subsection{Mobile Learning in Higher Education}

Mobile learning was developed as a strategy to address the challenges faced by educators and students in classrooms - learning, homework, access to information, and independent learning. With a different set of tools and resources becoming continuously available, mobile learning has gained credibility as having the potential to improve options for the personalization of learning. Scholars who have studied the characteristics of mobile learning in classrooms concede that m-learning allows students to work cooperatively, in teams, or independently, to accomplish a variety of tasks, for example to resolve research problems, work on assignments, meet separate needs, and allow for pupil voice and choice (Al-Emran, Elsherif, \& Shaalan, 2016; Santos \& Bocheco, 2014). With access to so much content anytime and anywhere, there are plenty of opportunities for formal and informal learning, both inside and outside the classroom (Keegan, 2005; Knezek \& Khaddage, 2012).

Mobile learning helps to characterize ways to address a number of educational difficulties. For a post-industrial world, mobile devices such as smartphones and tablets permit innovation at different levels and help teachers and students or even parents to gain access to online or digital content. They make personalized or individualized uses possible. Keegan's (2005) study showed that mobile notebooks, mobile tablets, iPod Touch, and other types of iPads are very popular devices for mobile learning because of their affordable cost and easy availability of applications. These devices have been used for collecting students' responses, accessing content in electronic books and websites, recording reflections, documenting field trips, collecting and analyzing data, and much more (Keegan, 2005).

Other studies have reported that students' dominant use of iPads has to do with conducting research as well as using as a device to support learning in a range of areas while using both "Apps or Applications" and other multimodal tools found on the iPad (Gasparini, \& Culen, 2013). The multimodality theory advocates an understanding that communication, when using a device such as the iPad, occurs through multiple but synchronous modes such as images and graphics from the camera or the Internet, touch using the touch screen, and audio input and output. Sneller (2007) describes an earlier study with a class where students used a tablet PC. Sneller's study showed that students had a positive attitude toward the use of the tool that supported their active learning styles. The study also showed that much more work was required from the teacher; the effective use of the tool implied a major redesign of the curriculum to be taught in a classroom. 
Teachers have reported also using the iPad as an assessment tool or using its features (such as sound and video recording) in summative and formative assessment. Some teachers reported evidence of other uses, such as learning and easy sharing of assessments within the classroom (e.g., with Apple TV) and beyond (e.g., emailing files, storing data on the school network or cloud-based systems such as Dropbox (Beauchamp, \& Hillier, 2014). In sum, these uses show promise, and students can develop valuable research skills at a young age. Technology gives students immediate access to an abundance of quality information that leads to learning at a much quicker pace than before. Students and teachers have access to an array of materials - that is, there are plenty of resourceful, credible websites available on the Internet that both teachers and students can utilize. The Internet has grown to be a credible source for a variety of content and does not limit students to one person's opinion, and verification of perspectives can be quick. While face-to-face interaction is huge, especially among the younger students, studies have shown that students work better when they work at their own pace (Ames, 1992). Online education is now accredited and has changed the way we view education (Saxena, 2008).

Using online tests as ungraded practice tests or low stake assignments can provide a useful self-check tool for students and greatly reduces concerns about cheating. Online tests can address student demands for exam study guides and provide students with an online practice test a few days before a traditional exam (Gogno, 2014).

\subsection{Uses of the iPad in University Classrooms}

The iPad has a vast number of unique features that display interesting possibilities in teaching and learning. The motion sensor of the iPad has a number of engaging applications for learning. Most students today would be classified as bodily-kinesthetic learners. The motion sensor enables the students to use their hands in guiding the iPad to equilibrium, recognize and balance their skills, or use remote control of real or virtual robotics, hovercraft, or other vehicles. Students can use the Clinometers app for measurement courses such as measuring the level of a wall, or surface, and the precise angles of incline or decline. With the internal accelerometers in the iPad, physics experiments of acceleration or change in force can be measured (Mango, 2015).

With the help of an iPad, students can attach videos and voice recordings to their field notes or in class notes (Hahn, \& Bussell, 2012). They can use different Apps to write voice notes, such as using the Dragon Dictation app, and it will type their words. With iPads in the same network but in different locations, using the Assemble app, students can create a collaboration web to share findings and discuss conclusions about different perspectives of the same project (Karsenti, \& Fievez, 2013).

In addition, iPad also enables in-class interaction of the students as well as their professors, by creating certain discussion boards, allowing the instructor of the course to know students' ideas on a particular topic. iPad is also used to post certain tasks or assignments that are assigned to students for a particular topic. Through such discussion boards, students can inform instructors about difficulties that they encounter with particular course materials and areas where they are unable to make progress (McLeod, 2015).

In math classes, for example, iPad applications are becoming more useful. Students can use the included Map application to calculate distances and compare routes and actual traveling speeds in real-word problems. In addition, the mathematics involved with trip-planning and decision-making are brought to life with real-time photographs, maps, and weather data provided by the Google Earth Apps, Big Blue Marble HD, or any others. For example, the App called Tour Wrist allows students 360 degree "tours" of locations of interest throughout the world (Teo, 2012).

The use of the iPad in the classroom has resulted in improvement of communication between students and instructors. With this device, documents can be shared or emailed straight over to peers while a lecture is in progress in the class. Students are able to submit their homework by email, or through the university's virtual learning environment. Also, teachers are enabled now to record students absenteeism using their iPad. This means that there is a centralized record of students' attendance in classrooms with which every teacher can access (Mang, \& Wardley, 2012).

\subsection{Advantages of Mobile Learning}

Mobile learning has played a very important role for the improvement of education environments of students in different fields of study. Through m-learning students are able to use, for example the iPod, to access learning anytime, anywhere as an educational tool, making it more convenient to learners. Along with their day-to-day activities, learners have the advantage of capturing any moment that is related to the topics that they are studying, and sharing it with their professors, such as between meetings or during weekends, focusing on the subject they want to learn. This helps students to increase their study times and eventually contributes to better grades during exams. Learning becomes more convenient in terms of studying anywhere, if by chance they needed to be elsewhere while their examinations were occurring; in such a case, the device is a great asset to them (Mehdipour, \& Zerehkafi, 2013). 
Mobile learning encourages students to engage in collaborative learning, allowing learners at different locations to get in touch with their peers or others teams to discuss and learn the topics that are being taught to them. It becomes a type of social learning. Social learning is a current trend that creates a sense of competition and cooperation among the students, which will help learners to focus on the courses they are engaged in along with the supportive environments that they create along with their peers. It is one of the techniques by which to develop teamwork and supportive skills that will be required by students in the job market (Sarab et al, 2012).

Furthermore, mobile learning boosts learners' engagement in education. Learning and training at the workplace mostly consist of verbal and desktop communication, which requires some kind of technology to become more attractive and interactive. Adapting interactive mobile devices can bring several opportunities to engage the worker / learner on a digital and social level outside of the work. This new dimension will erase the sense of boredom in learners' minds about the course and the tasks that they are involved in. A variety of meetings and presentations in the workplace or the university classroom can be done with the help of an iPad or laptop. Because these devices are interactive, they can facilitate comprehension of the information that employees or students want to convey to professors or managers (Rueckert, Kim, \& Seo, 2013).

Mobile learning encourages self-paced learning. No learners are the same; each has his or her own way of studying and understanding contents of the materials that are part of an assignment (Henson, 2003). With the help of mobile learning, students are now able to learn in their own style, and at their chosen place and pace. In a classroom setting, it is conceivable there will be few learners who have not understood concepts taught to them and still hesitate to ask for explanation. In mobile learning, nobody knows or cares how many times you revisit the course site or materials, an opportunity which gives learners the freedom to revisit the passage until they have understood it. This feature turns out to be one of the advantages that students have in working with digital devices in mobile learning (Asabere, 2013).

iPad's features enable students to address their learning styles that are required to understand concepts being taught in classrooms. Through mobile learning, students can fit different learning styles into the digital environment. Mobile devices allow them to read the chapters of an e-book without physically carrying heavy books. In addition, learning through videos related to course topics can enhance learning as well. Listening to podcasts (audio) related to research, the ability to surf on the Internet for information required by their professors, or the completion of a report task makes schoolwork fun and learning tasks not only easier to accomplish but also enjoyable (Ally, 2009).

One of the principal advantages of using mobile devices to deliver courses and training is security. Mobile devices are tightly integrated within the corporate network of a server, and many of the technical and security hurdles are already handled by existing applications embedded in the digital infrastructures. Furthermore, students on mobile platforms practice and undergo self-focused learning. This type of m-learning is a great opportunity for training or review of content. It has also shown to improve the problem-solving skills of the students. This is possible because these m-learning methods facilitate collaboration among students and instructors through asynchronous and synchronous communication techniques (Asabere, 2013).

Mango (2015) showed the link between an iPad and students learning in a classroom. His study indicated that students enjoyed using the iPads and believed that iPads helped them learn. Students also believed that the mobile devices facilitate their participation and collaboration in class. Mango's study results are significant because as was stated earlier, the more students are engaged in their learning, the more they are likely to succeed in college. In sum, there is a link between engagement and students' academic achievements and persistence in college. Equally, collaboration is linked with students' success as it "enhances academic achievement, student attitudes, and student retention" (Mango, 2015).

Another benefit of m-learning is its ability to improve students' productivity by making knowledge and learning available anytime and anywhere, enabling learners to participate in learning activities without traditional place and time restrictions. Mobile technologies support more accessible and more widely available learning than the learning that is used in existing e-learning environments. M-learning enhances two-way interaction and supports direct communication between students and their teachers in such way as to encourage shy or hesitant students to communicate more easily than in face-to-face classrooms.

Teachers with large groups can use the direct interaction as a way of giving special instructions to all students. M-learning helps students facing financial, family, or health problems in migrating out to university classes. Finally, $\mathrm{m}$-learning is self-motivated and self-disciplined; it supports studying without wasting time resulting from travel time to libraries: mobile devices allow studying at anytime and anywhere (Sarrab, Elgamel, \& Aldabbas, 2012). 


\subsection{Challenges of Mobile Learning}

Although mobile learning contributes much to the learning environment of students, it definitely has certain challenges that should be taken into account. As most of the work in mobile learning is done through connectivity to a network, the issue of connectivity could be a concern. Students may encounter connectivity problems while uploading and downloading information because of poor or totally absent mobile network signals. There also might be limited availability of Internet networks in many places (Behara, 2013).

Device compatibility is another challenge facing students. Most of the iPad devices are unable to open flash format files, making it difficult for some students to attain the required information. With the increasing availability of manufacturing resources, dozens of varieties of mobile phones are coming into the market every day that enable the opening of such formats, but not all devices are equipped with it. Learners may possess a mobile device that may or may not support the type of content that learners want to access (Mcconatha, Praul, \& Lynch, 2008).

Furthermore, mobile learning tends to be a kind of distraction to students. This is also the reason that most students move toward buying devices that provide them solitude; i.e., it enables them only to read the chapters or sections required for their studies and not any other distractions. Most of these devices are the ones that come with only one feature (reading), which creates zero distraction, at least from within the device. On the other hand, in terms of accessing the course through mobile devices, if the learner gets a call, SMS, or social media update, this learner is bound to get distracted. It moves their minds and thoughts away from what is being taught in the classroom, which may affect them later during the examination periods (Liu, Navarrete, Maradiegue, \& Wivagg, 2014).

Moreover, the cost of mobile devices is another burden for most students. Mobile learning requires the use of any technological device that offers individuals the opportunity to make it useful for their education. Therefore, an individual may feel compelled to purchase a device that he or she cannot afford. Even if individuals are able to purchase such a device, it may require constant upgrading within a year or two, which may also turn into a high cost. In addition, there are typical monthly charges for data usage. If someone requires a large file, for example, it may require a high cost and much time to acquire.

Students have also faced the challenge of maintaining battery life for their mobile devices. The battery life of most of these devices lasts for an average of 10 hours, but this is often not enough time for the tasks that the students have to do. However, electrical outlets within the classroom might help students recharge their devices. Current mobile devices have limited storage capacity, which might not be effective in displaying or storing some e-books that require large memory spaces. However, there are a number of devices being invented every year with increased storage capacities (Yang, \& Wang, 2003).

The study of mobile learning is timely because of the proliferation of mobile technology in society, globalization, and the need to re-examine how learning materials are designed and delivered for the new generation of learners. In today's world, people are on the move and are demanding access to learning materials and information anytime and anywhere. At the same time, there is increasing use of mobile technology in different sectors of society to meet the needs of people on the move. In business, there is increasing usage of mobile technologies for individuals to conduct their business anywhere and anytime.

In healthcare, medical staff are using mobile technologies to access just-in-time information and to enter information in real time. People working in the field away from the central office use mobile technologies to access information and to communicate with other workers. In addition, younger generations of learners are using mobile technologies for entertainment and socialization. These learners are using mobile devices to access information and multimedia materials and to communicate with friends. These new generations of learners do not see technology as something foreign. They readily accept technology and consider technology to be part of their lives. Moreover, the use of mobile technology is a 21st century skill that students and workers must have to function in society (Ally, 2007).

iPad was commonly agreed on by students and academics to be easy to use. Students found iPad to be a useful tool to increase flexibility, portability, and productivity because it is small, easy to use, and Apps can be loaded frequently. Although students found it easy and enjoyable to use, they were neutral about using iPads in learning. However, both academics and students shared their concerns about the application costs and that the technology becomes outdated quickly. The value was not sufficient to justify the cost of the device and its companion Apps (Nguyen, Barton, \& Nguyen, 2014).

Past studies have observed that students who are used to learning in the presence of individuals who share the same experiences were less encouraged to listen to digital recordings because of feelings of separation. For example, sitting 
alone at home and hearing the course on the computer were features that led to the loss of motivation described by applicants (Khechine, Lakhal, \& Pascot, 2013).

\subsection{Mobile Learning in the UAE}

A scan of the recent literature reveals that there is not much published on m-learning in the UAE even though there are multiple contexts and environments where technical and pedagogic aspects of m-learning thrive-e.g., in the sciences and engineering (Al-Emran, et al., 2016). To ascertain these emerging uses requires infusion of budgetary resources (that is, finance and money but also human resources, physical estates, institutional reputation, intellectual property, and expertise) and culture (that is, institutions as social organizations, their practices, values, and procedures, but also the expectations and standards of their staff, students, and their wider communities, including employers and professional bodies).

Equally, studies recognize that when technology drives the quality and influence of the lessons, students perform better (Khechine, Lakhal, \& Pascot, 2013). The engagement phase of technology is an additional important advantage. Clearly, all learners require encouragement and a variety of learning approaches to overcome boredom and other motivational challenges. In sum, technology suggests to students the chance to practice as they learn, using their hands and minds (Ally, 2007).

Another observation is the legacy of "face-to-face that has been the mainstay of learning enterprises. Many online actions offer instant graphic and/or verbal reaction with greetings or alterations. Students whose teaching comprises music videos are improving their listening skills. There is constant tension between on-line and face-to-face teaching and learning. While there is notable gain of technology use in the UAE with objects such as mobiles and iPods, one can observe tension between the mode of learning students prefer and instructors 'demands. Students want to have more control over their learning than anybody else does. They can do exercises the way they decide, or change to another items. They have the ability to state which actions are most significant to their desires and concentrate on them (Ball, 2011).

Instructors do not have to know everything, but they should know how to teach, how to simplify, and how to inspire students to learn. Here is where we need a face-to-face approach, to deliver the information correctly. Online teaching will work for content transmission. However, a face-to-face lecture allows for an engaging discussion. It gives the students the chance to ask and understand unclear points easier (Kemp, Preston, Page, Harper, Dillard, Flynn, \& Yamaguchi, 2014).

Implementing wireless and mobile education within higher education must address these social, cultural, and organizational factors. They can be formal or explicit, or informal and tacit, and can vary enormously across and within institutions. Within institutions, different disciplines have their own specific cultures and concerns, often strongly influenced by professional practice in the "outside world"- especially in the case of part-time provision and distance learning. Because most work in mobile learning is still in the pilot and/or trial phase, any explorations of wider institutional issues are still tentative, but it points to considerable hurdles with infrastructure and support (Traxler, 2007).

In addition, it can be taken as a given that all students in all universities and colleges in UAE own or have access to a mobile phone which they consult constantly. All students enrolled in higher and further education institutions today have frequent needs for information from their institutions about timetable changes, assessment deadlines, feedback from tutors, and other urgent administrative details. The use of mobile telephony is a much more efficient and quicker means of communication than postal contact or email. Once this has been achieved, the use of mobile learning for academic contact in colleges and universities can be added (Mehdipour \& Zerehkafi, 2013).

It is true that many college students have regular access to personal computers, delivering notes and study materials and even exams through course management systems; it has taken more than a decade for this technology to reach the level it has in the UAE. Most students recognize that the personal computer may be a technologically more advanced medium, but it is not portable, and so it is not something students are likely to carry around with them on a day-to-day basis. M-learning does not seek to replace the utilization of computers to aid in learning, but rather to supplement it with interesting new methods that use a preferred medium increasingly available to students at affordable prices and already widely in use (Mcconatha, Praul, \& Lynch, 2008).

\section{Research Methods and Findings}

The present case study examined the advantages and challenges students encounter when they engage in mobile learning in higher education. In the larger study, which consisted of a quantitative survey and qualitative interviews, a mixed methods approach was used with open-ended and close-ended questions that were developed to capture the 
dynamics of the m-learning environment at UAE. Some 400 respondents were polled from a convenient sample of UAE students.

Different academic disciplines were represented. Questions in the data-gathering instrument were designed to probe respondents' perceptions on the types of technologies used in higher education and how the devices were engaged in the day-to-day learning at the university. Namely: (a) the extent of use; (b) the benefits of encouraging mobile technologies in classrooms; (c) and establishing whether mobile learning can outpace current face-to-face teaching styles and learning applications. This article reports on the qualitative portion of the study while the survey data analysis is ongoing.

Applying grounded theory research techniques, the present study revealed the study's themes based on the findings, to generate a theory from the data to explain the dynamics and intricacies of m-learning (Conrad, 1978). Geertz (1973) assumes data must be read and reread to interpret and uncover the themes. This reflective practice and analysis revealed basic assumptions of mobile devices and m-learning practices. Key themes from the literature were examined on a deeper level: (a) the nature of mobile learning in broad contexts; (b) mobile learning in higher education; (c) the proliferation of iPad uses in university classrooms; (d) the challenges of mobile learning; and (e) the challenges of mobile learning.

\subsection{Research Design}

This case study approach was selected due to the defined boundaries of the participants and the particular topic being researched (Creswell, 2007, p. 74). The steps taken were to: (a) define a problem; (b) review literature for the historical context of and current research on the problem; (c) select participants; (d) schedule interviews with participants; (e) conduct interviews; (f) transcribe interview data; and (g) analyze and report outcomes. Permission was received from the university prior to any contact with potential study participants.

\subsection{Participants}

Participants for this study were defined and purposely selected; participants had to be currently enrolled students at UAE University. Potential interviewees were randomly selected from individuals who participated in the cross-section survey of this study. Table 1 presents the demographic characteristics of the participants.

Table 1. Demographic characteristics of participating students

\begin{tabular}{llll}
\hline Factor & & Frequency (N=616) & Percentage \\
\hline Gender & & & \\
\hline & Male & 17 & 17.4 \\
\hline Age & Female & 509 & 82.6 \\
\hline & & & \\
\hline & $18-22$ & 443 & 71.9 \\
\hline Academic Major & & 165 & 26.8 \\
\hline & $31-45$ & 8 & 1.3 \\
\hline & Business \& Economics & 74 & \\
\hline & Education & 83 & 12 \\
\hline Law & 21 & 13.3 \\
\hline Medicine & 7 & 3.4 \\
\hline Science & 82 & 1.1 \\
\hline Engineering & 59 & 13.3 \\
\hline Food \& Agriculture & 22 & 3.6 \\
\hline Humanities \& Soc. Sciences & 254 & 41.2 \\
\hline Information Technology & 15 & 2.4 \\
\hline
\end{tabular}




\subsection{Limitations}

Participants were purposely chosen for this study from one large public university in the UAE. Participants who did not participate in the survey or represented a different type of institution (e.g., small liberal arts college or private university) might have had different access levels with mobile devices or demands of assignments. The aim of this study was to understand the experiences characterizing the use of mobile devices in higher education.

\subsection{Method of Data Collection: Interviews}

To understand the foundation of qualitative research and essentials in understanding how participants view their world (Rossman \& Rallis, 2012, p. 176), this researcher conducted structured interviews with open-ended questions to uncover the assumptions and perceptions of university students and the extent they rely on mobile devices for their academic tasks. Questions were designed to determine whether mobile devices add value to the educational enterprise. How do processes of e-learning compare to face-to-face teaching and learning? Or with other computer-assisted teaching? Following the guidelines established by Creswell (2007), an audio recording device was tested prior to the interview, and an interview protocol was created, tested, and refined (p. 133). The one-hour interviews were conducted one-on-one in a convenient location chosen primarily to accommodate the participants and enabled the researchers to "develop a level of detail about the individual or place and to be highly involved in actual experiences of the participants" (Creswell, 2003, p. 181).

\subsection{Researcher Positionality}

Prior to conducting any interviews, the researchers reflected on "researcher positionality" and personal assumptions. This refers to reflections that suggest that the researcher's identity requires manipulation in order to facilitate the research process and product without omitting identification of the effects which undertaking research has upon the identities, relationships, and emotions of all participants (i.e., "researcher" and "researched").

Coffey's (1999) insistence on an explicit recognition that researchers, accompanied by their epistemological and conceptual baggage and concomitant life experiences, permeate and suffuse the entire research enterprise represents a view that is supported by Sword (1999, p. 277) and acknowledged in this study. Given that the researcher is, in this view, intimately involved in both the process and product of the research enterprise, it is necessary for the reader to evaluate the extent to which an author identifies and explicates their involvement and potential or actual effects upon the findings.

Because the researcher is a member of the faculty at UAE, it was important to refrain from interjecting in conversations with interviewees and to let them tell their story without coloring from the interviewer. Respondents were left to explain their relationships with technology, mobile devices, iPads, and other academic uses. Any comments by the researcher would be deemed an unwarranted influence or a redirection of the interview process.

\subsection{Data Analysis}

According to Bogdan and Biklen (1998), "analysis involves working with data, organizing them, breaking them into manageable units, synthesizing, searching for patterns, discovering what is important and what is to be learned, and deciding what story you will tell others" (p. 157). Qualitative data for the present study were collected from structured interviews and transcribed verbatim into 50 pages of text. A line-by-line analysis of the text was conducted in order to generate categories and themes within each category. The text from each category and theme was grouped and analyzed to determine any patterns.

In this study, I employed the grounded-theory data analysis approach. Charmaz (2006) suggests, "we do not force preconceived ideas or theories directly upon our data. Rather, we follow leads that we define in the data, or design another way of collecting data to pursue our initial interests" (p. 17). Table 2 illustrates the initial data coding: 
Table 2. Data coding

\begin{tabular}{|c|c|c|c|}
\hline Question & Category & Themes & $\begin{array}{l}\text { Data source: } \\
\text { Pseudonyms }\end{array}$ \\
\hline $\begin{array}{l}\text { What are the advantages of } \\
\text { integrating mobile learning in } \\
\text { classrooms? }\end{array}$ & $\begin{array}{l}\text { Learning with Technology - } \\
\text { How students use iPads in } \\
\text { their classes }\end{array}$ & $\begin{array}{l}\text { advantages of integrating mobile } \\
\text { learning in classrooms } \\
\text { uses of technology in classroom } \\
\text { by students and teachers }\end{array}$ & $\begin{array}{l}\text { Shamna } \\
\text { Maria } \\
\text { Rukshana } \\
\text { Noor } \\
\text { Ameera } \\
\text { Shaya } \\
\text { Sayeed } \\
\text { Zainab }\end{array}$ \\
\hline \multirow[t]{5}{*}{$\begin{array}{l}\text { What are the challenges of } \\
\text { integrating mobile learning in } \\
\text { classrooms? }\end{array}$} & $\begin{array}{l}\text { Challenges } \\
\text { Other uses of iPads }\end{array}$ & $\begin{array}{l}\text { Students' use of iPads in their } \\
\text { classes }\end{array}$ & $\begin{array}{l}\text { Shamna } \\
\text { Rukshana } \\
\text { Nida } \\
\text { Yuta } \\
\text { Adham } \\
\text { Boman } \\
\text { Maiam } \\
\text { Ameera } \\
\text { Anaud } \\
\end{array}$ \\
\hline & Other challenges & $\begin{array}{l}\text { Other ways to use the iPads in } \\
\text { learning class content }\end{array}$ & $\begin{array}{l}\text { Shamma } \\
\text { Maria } \\
\text { Rukshana } \\
\text { Nida } \\
\text { Adham } \\
\text { Boman } \\
\text { Noor } \\
\text { Shaya } \\
\text { Sayeed } \\
\text { Fadi }\end{array}$ \\
\hline & $\begin{array}{l}\text { Students cannot deal with } \\
\text { technology }\end{array}$ & $\begin{array}{l}\text { Navigation } \\
\text { (Problems with connecting the } \\
\text { devices) }\end{array}$ & $\begin{array}{l}\text { Boman } \\
\text { Mariam } \\
\text { Mohamad } \\
\text { Ahmed }\end{array}$ \\
\hline & & $\begin{array}{l}\text { Using technology affects student's } \\
\text { health }\end{array}$ & $\begin{array}{l}\text { Rahma } \\
\text { Ammar } \\
\text { Shamma } \\
\text { Nahal } \\
\text { Anoud }\end{array}$ \\
\hline & & $\begin{array}{l}\text { Not having sufficient know-how to } \\
\text { use technology for learning } \\
\text { Limited infrastructure }\end{array}$ & $\begin{array}{l}\text { Shamma } \\
\text { Mariam } \\
\text { Rahma } \\
\text { Nahal } \\
\text { Anoud } \\
\text { Salman } \\
\text { Ammar }\end{array}$ \\
\hline
\end{tabular}

\section{Findings of the Qualitative Study}

The major findings of this study permit a discussion of the advantages and challenges of m-learning among UAE University students. Overall, students were aware of the use of m-devices, particularly iPad technology, in their classrooms. Here is a list of students' opinions as summarized from their responses:

1. Students indicated that the use of mobile technology in their education was very important to develop research skills. 
2. Students agreed that technology could be used as a communication tool to help students learn and improve their study skills.

3. Students prefer to use technology for online test-test taking in the university.

4. Mobile learning plays an important role to develop and nurture the education and learning environment for students.

5. Mobile learning allows students to work collaboratively with peers or in teams. They can discuss academic issues and learn from each other-an important aspect of social learning.

6. Technology helps students to learn with different learning styles for different activities, for example using video player, pictures, or recorded audio.

7. Students can be creative by using a variety of Apps that help to enhance creativity, foster creativity, and become better organized.

8. Most students said technology helps with the overall learning process and in effective ways, especially with information-sharing tools.

9. M-learning improves student's productivity by making knowledge and learning available anytime and anywhere.

10. M-learning supports direct communication between students and their teachers.

11. Students believe technology increases in importance as time passes and helps everyone to save time.

12. Students prefer to use iPads because they are lighter than books and easier to carry from class to class.

\section{Discussion}

The aim of the present study was to scrutinize the variability of factors including student academic skills, definitions of mobile learning, benefits, challenges, disadvantages, and the diverse uses that each student brings to mobile technology. The findings presented in this paper are comparable to previous studies in the Gulf States, such as Oman, Qatar (Al-Emran, M., Elsherif, \& Shaalan, 2016; MacLeod, 2015). Here is what these studies found:

1. Mobile technology is a useful tool for my study.

2. Mobile technology can offer opportunities for communication and teamwork.

3. Mobile technology can help me in finding resources related to my study.

4. Mobile technology can bring many opportunities to the learning process.

5. Mobile technology can help me to access the course material anytime, anywhere.

6. Mobile technology can be an easy way to get feedback and notifications from my instructors.

7. Mobile technology can help me to exchange the course material with my friends.

8. Mobile Apps can help me to manage my study.

9. Mobile technology can help me to do my coursework.

10. Mobile technology can help me to develop my learning skills (Al-Emran, Elsherif, \& Shaalan, 2016, p. 97).

The picture that emerges from this comparison shows that the findings of the present study did not differ much from responses provided by students from other parts of UAE or other countries in the Gulf region. The striking difference, however, is that in the present study, faculty members did not participate in the survey even though a few teachers were selected to validate the responses from students. This study was not primarily for teachers.

\subsection{Opportunities of Mobile Learning}

From the outset, the present study was designed to search for the opinions of current university students on whether they see opportunities in the mobile technologies they use in university classrooms. Students seemed to agree that many advantages exist, and the iPad and recent smartphones seem to be the most popular in use. Students' views seem to agree or coincide with Saxena (2008) that students can develop valuable research skills at an early age. In addition, technology gives students immediate access to an abundance of information, which leads to learning at a faster pace than before.

As one respondent, Nida, remarked: "in my law classes and other university courses, I have to do lots of research to learn and finish my education. Today's technologies make assignments and assessments easier to do." Nida was convinced that mobile technological devices have made access to books, articles, and course-related information from 
all over the world readily available to students. In addition, mobile learning helps students learn many skills, as suggested by Keegan (2005) when he pointed out that mobile learning in classrooms often has students working interdependently, in collections, or independently to resolve problems, to work on assignments, to meet separate needs, and to allow for students' voices and choices.

In addition, these insights reinforce what another respondent, Rukshana, said in the interview: "technology in the classroom is the best learning tool because with classroom technology, students are more engaged, have improved collaboration, and most importantly, see learning as fun!" The iPad is used in the classroom to link students. The results indicated that students not only enjoyed using the iPads but also believed that the iPads helped them learn. Students also believed that the devices facilitated their participation and collaboration in class.

These results are significant because as was stated earlier, the more students are engaged with their learning; the more they are likely to succeed in college, as there is a link between engagement and students' academic achievements and persistence in college. Collaboration is also linked with student success as it enhances academic achievement, student attitudes, and student retention.

Students in the study articulated the many uses of mobile devices. The frequency of use leads to discovery of more and better opportunities in benefiting from these digital tools. The new applications keep popping up in classrooms. Beauchamp and Hillier (2014) found that teachers invent new ways to ease or facilitate their work. For example, they described the ways in which features of the iPad such as sound and video recordings are a charm to students and a lure to deeper research. Beauchamp and Hillier detailed evidence of learning and assessments derived from Apple Tv and beyond, such as emailing files or storing on school networks or cloud-based systems, such as Dropbox. Another respondent, Noor, noted this phenomenon: different digital technologies (e.g., iPads, laptops, smartboards) were used in a variety of ways during classes.

The use of mobile devices to contact teachers was yet another added feature of digital technologies. "The technology can be used as a communication tool that helps students to learn more and provide link between students and teachers." This confirms Colin's (2012) findings that showed that the use of the iPad in classrooms resulted in significant improvement of communication between the students and their instructors. For example, students are able to submit their homework by email, or through the university's virtual learning environment. Rahma observed that this is true in her classes: "mobile technology is also used when the professor wants to share something with the students related to the course regardless of whether it is a video or a document. The professor is able to share things with the class via Blackboard or through email. Both my email and my Blackboard are on my iPad so I can easily access whatever the professor sends me."

Digital technologies have enabled mobile learning in leaps and bounds. Respondents' comments referenced ways in which mobiles are used to prepare them for online tests, assessment, and communication of grades. For example, Salem, a respondent, mentioned, "professors should make all the exams and tests to be taken on the iPad to save paper and to ease grading by professors. Also it is possible to save money and time for professors." Gogno's (2014) and Mehdipour (2013) studies raised these issues when they suggested that the use of online tests as ungraded practice tests or low stake assignments provides a useful self-check tool for students and greatly reduces concerns about cheating. Equally, online tests can address student demands for exam study guides and provide students with an online practice test a few days before a traditional exam.

\subsection{Integrating Mobile Learning in the Classroom}

Mobile learning has played a role in the improvement of educational environments of students in different fields of study. Through mobile learning, students are able to access learning anywhere, anytime, thus making it more convenient to learners. Along with their day-to-day activities, learners have the advantage of capturing information related to topics that they are studying. It is also possible to share such information with their professors in meetings or online. Learners find it convenient to be able to study anywhere and if by chance they have to go somewhere when examinations are underway, mobile devices can turn out to be a great asset to them.

Students find it inevitable to integrate mobile learning in the classrooms since they frequently use those mobile devices in their social lives. One of the respondents, Rukshana, observed, "the availability of 'Blackboard' in all my lectures, or the omnipresence of e-mail through which I can interact with my classmates and professors has become part of the learning that takes place at the university."

Different Apps have been introduced to classrooms that students can use for academic study and for presentations in class such as PowerPoint. Adham commented that "the ability to take notes on the MacBook and save them so that I don't ever lose my notes, accessing information on a big screen and being able to interact with the instructors on 
specific applications used throughout the classes is an added value to my education." Anoud stated that with the iPad, for example, students could receive answers to queries in different ways. Another respondent, Mughair, said, "notetaking whenever and anywhere without any paper or pen is just cool; to make presentations with certain Apps; and reading books we like online." She added that the "Blackboard App" has been a time-saver, particularly in doing calculations. These responses confirm that current students completely rely on mobile learning. The digital products now available on the market have capitalized on these sentiments. These findings are encouraging to the developers of Apps and no doubt, the market will add digital works that compete for applications and sophistication.

Mobile learning in the classroom encourages students to learn collaboratively, allowing learners at different locations to get in touch with their peers or other teams to discuss and learn the topics that are being taught to them in their schools or universities. It turns to be a kind of social learning, which is a current trend that creates a sense of competition and cooperation among the students, which will help the learners to focus attention on the courses they are taking along with the supportive environments that they create with their peers. It is teamwork technique that fosters collaboration and supportive skills that will eventually be required of students when they enter the job market. Maria, a respondent, said that a successful use of devices depends on the number of iPads in the group, for example. "If each group has only one iPad, then students are more likely to share it, and work in a collaborative manner. On the other hand, in a group, if each and every person has one iPad, it can be very detrimental to their teamwork, as they might all get engrossed in their work, and not interact, and thus defeat the whole point of collaboration."

Yuta commented that it uses of the iPad is beneficial to some extent. It can be useful to collect information and communicate with each other. However, a collaborative group would fail when the group members rely on the Internet too much, which means they would not often meet each other. Adham added that iPads are beneficial but not necessary. Group collaborations with the use of technology make everything easier, in terms of communication, transfer of files, email communication, and the ability to work on the same documents simultaneously.

Shamma commented that iPads helped with class activities because they provide the content needed to solve problems. Likewise, Nida concurred when she said "things I like using on the iPad include the notes, the word processing application, the video player and the accessibility and the mobility which aids in accessing information easily. In addition to that, I can take pictures and record audio memos during class and it always helps in revision afterwards." Yuta further added, "mobile devices have helped me a lot in the way that I can look at dictionaries or necessary information while I am taking a lecture. In addition, I do not need to carry all of my textbooks everyday anymore."

With the help of some applications such as Nearpod, for example, the professor can help students pay attention and interact with the lecture rather than just sitting and looking as the professor is giving the lecture. Mughair commented, "it has affected our problem solving skills, it exposed us to technological environment by making our work easier. For example, using certain Apps like AutoCAD, students are able to create their own designs by using the tools provided. It made the work clearer for making maps, especially compared to the days when maps were drawn by hand in pencil, and corrections were confusing and problematic to understand." Nahal agreed with that by saying, "I was also able to get more creative as it was a tool to express our creativity through different 'Apps.' There are many 'Apps' that help enhance creativity and encourage there to be a form of development so it helps us become more organized and shape things in a better way."

In mobile learning, nobody knows or cares how many times you revisit the course, which gives you the freedom to do it until you have understood it. Therefore, this turns out to be one of the major advantages that students have received through mobile learning. Nahal said that the iPad has created a more fun environment in the classroom. In a way, it is self-enhancing and collaborative at the same time. The comments affirm earlier observations that current students seem to relate to technology like "digital natives. Therefore, having such a digital tools in class has helped students keep focus better and want to achieve better things and make students want to achieve more.

While students recognize the differences between laptops and iPads, such as size, capacity, battery life, and even more, they prefer using laptops rather than iPads. Manal commented, "I prefer to use my laptop because I feel that my work is secure more than in the laptop and also I feel more comfortable using it." In addition, Mohammed said, "a laptop helps with the overall learning process and is considered effective as an information-sharing tool; data input is more efficient and easier to organize." These comments illustrate the emerging trend to glorify the computer in the many ways which students have found to facilitate their learning — such as engage students in complex calculations that would be tedious or time-consuming on paper. In today's estimations, students deem yester years of paper calculations are a waste of time and effort (Ammar).

In sum, the students perceived the benefits of m-learning, especially in its potential for improving students' productivity by making knowledge and learning available anytime and anywhere, enabling learners to participate in 
learning activities without traditional place and time restrictions. Mobile technologies support accessible and widely available learning more so than the learning that takes place in existing e-learning environments. M-learning supports performance with easy access to information, which can immediately affect students' performance in a learning environment, facilitating their education so that they can save most of their time for studying.

Further, M-learning enhances two-way interaction where it supports direct communication between students and their teachers, in such a way as to encourage shy or hesitant students to communicate more easily than in classrooms. In addition, teachers of large groups can use the direct interaction as a way of giving special instruction to all students. M-learning also helps those students facing financial, family, or health problems in migrating out to university classes. Hence, in this study, iPads, according to students' perceptions, were found to enhance students' learning and engagement with classroom activities facilitating students' collaboration between each other and their participation in classroom activities.

\subsection{Challenges Students Encounter in Using Digital Technology in Higher Education}

In response to the question on the challenges, respondents stated the following:

1. Many students said there were connectivity problems while uploading and downloading the information, as well as a lack of availability of Internet connection in many places.

2. Furthermore, technology can cause severe health issues, such as eyesight problems.

3. There are many students who cannot handle mobile learning because they do not have enough experience with using technology, or they have problems understanding the new programs.

4. Limited battery life is an issue because batteries lose charge quickly and take time to recharge.

5. Storage space is small and affects their iPad productivity.

6. Many of the UAEU students agree that technology is a source of distraction in classes because students play games or are on social media during class time.

Further analysis of these findings reveals that students' views concur with Behara (2013): as most of the works in mobile learning are done through connectivity to a network, connectivity is an important link. Mobile learning is supposed to happen anywhere, during your commute to the office or to the university, while you are travelling to attend a meeting out of town, or even when you are on vacation. During these times, there may be some connectivity problems while uploading and downloading the information because of poor or totally absent mobile network signals. It may also be due to the lack of availability of Internet networks in many of these places. Mohammad said "Of course nothing with benefit comes without harm, and the reliance on such technology can bring some major setbacks."

Regarding connectivity, Aisha commented, "Most thing that I have faced is internet connection when I want to post something on the blackboard, or working on online assignment or when I want to submit it, but the worst challenge is when I'm done with my work but I forgot to save it, then all of it fade and I need start from the beginning which makes it very difficult." Maria added, "Sometimes, we lose the internet connection or the Wi-Fi is slow. The textbook that is available on Blackboard fails to download sometimes. Even though we can access the 'Discussions' forum, it is harder to edit them on iPad."

Furthermore, mobile learning tends to be a distraction to the students. This is also the reason that most of the students tend to buy devices that provide them only with the ability to read the chapters or information required for their studies, and not other distractions. Most of these devices come with only one feature, namely reading, and this enables zero distraction, at least from within the device. On the other hand, in terms of accessing the course through mobile devices, if learners get a call, SMS, or social media updates, they are bound to get distracted.

\section{Conclusion}

The present study surveyed students enrolled in undergraduate courses to examine opportunities and challenges university students face when instructors introduce "structured" mobile learning in higher education. The results revealed that students use iPads, cell phones, and laptop computers to study anytime and anywhere. The results presented in this study, suggest that students' opinions are important and must be taken into account when developing policies for mobile device usage in the classroom due to students' personal needs and expectations. Mobile learning (m-learning) has become an important educational technology component in higher education. M-learning makes it possible for students to learn, collaborate, and share ideas with each other with the aid of Internet and technology. Turning off mobile devices during class time does not seem an appropriate policy for this particular group of students. 
This finding is significant in terms of policy and pedagogy implications. Currently, students are part of a global digital revolution. They are constantly browsing on-line or on social media. College-age students claim to be the digital commons of the future. They are comfortable using digital technologies to retrieve information, to communicate globally, and to process information quickly. They process information and learn differently than the previous generation. In sum, this study has touched only the surface of the metaphorical iceberg. More studies will be needed to examine these new characteristics and explore ways to adapt classroom technologies and pedagogies to meet the needs of this generation.

The new reality on the horizon is that learners and educators must accept m-learning as critical to employment and future development of m-learning systems. Attitudes toward m-learning technology are an important factor that helps determine whether learners and educators are ready to use m-learning. Understanding attitudes of learners and educators will serve to identify strengths and weaknesses, and facilitate the development of the digital technology infrastructure.

In a similar study conducted in neighboring Gulf States, researchers found similar results where different factors were examined to determine the differences among students and educators' attitudes toward m-learning, such as gender, age, country, level of study, smartphone ownership, and demographics including students' age, country, academic rank, academic experience, and smartphone ownership for educators. Findings revealed significant differences among the students' attitudes toward m-learning with regard to their smartphone ownership, country, and age. Such attitudes will serve to identify strengths and weaknesses and facilitate the development of the digital technology infrastructure. Furthermore, results indicated that m-learning could be one of the promising pedagogical technologies to be employed in higher educational environments within the Arab Gulf countries.

Collectively, the findings of the present study and those from previous studies usher in new thinking about educational technology. For example, in the present study, students viewed the iPad as a tool for self-improvement in the educational arena. At the start of the study, the iPad was also used for private purposes, connectivity, and self-representation in social media, but these uses were quickly abandoned. It seems that students have a need to separate the educational and the personal use of the iPad. On the other hand, it will take time for teachers and the university to adapt the curriculum to these new ways of using digital devices involving images, text, and audio. The potential is huge. Future research should focus on deeper and broader investigation of reasons for separating the personal and the educational use of tablets, as well as its implications.

\section{References}

Abu-Al-Aish, A., \& Love, S. (2013). Factors influencing students' acceptance of m-learning: an investigation in higher education. The International Review of Research in Open and Distributed Learning, 14(5), 93-102. https://doi.org/10.19173/irrodl.v14i5.1631

Al-Emran, M. N. H. (2016). Investigating students' and faculty members' attitudes towards the use of mobile learning in Higher Education. Computers in Human Behavior, 56, 3-102. https://doi.org/10.1016/j.chb.2015.11.033

Al-Emran, M., Elsherif, H. M., \& Shaalan, K. (2016). Investigating attitudes towards the use of mobile learning in higher education. Computers in Human Behavior, 56, 93-102. https://doi.org/10.1016/j.chb.2015.11.033

Ally, M. (2009). Mobile learning: Transforming the delivery of education and training. Athabasca University Press.

Ames, C. (1992). Classrooms: Goals, structures, and student motivation. Journal of educational psychology, 84(3), 261. https://doi.org/10.1037/0022-0663.84.3.261

Apple. (2010). An Apple product for every student. Retrieved January 20, 2013, from http://www.apple.com/education/labs/

Apulu, I., Latham, A., \& Moreton, R. (2011). Factors affecting the effective utilisation and adoption of sophisticated ICT solutions: Case studies of SMEs in Lagos, Nigeria. Journal of Systems and Information Technology, 13(2), 125-143. https://doi.org/10.1108/13287261111135972

Asabere, N. Y. (2013). Benefits and challenges of mobile learning implementation: Story of developing nations. International Journal of Computer Applications, 73(1). https://doi.org/10.5120/12706-9504

Attewell, J., \& Savill-Smith, C. (2004). Mobile learning and social inclusion: focusing on learners and learning. Learning with mobile devices: research and development, 3-11.

Ball, N. (2011). Technology in adult education ESOL classes. Journal of Adult Education, 40(1), 12. 
Barbera, E. (2004). Quality in virtual education environments. British Journal of Educational Technology, 35(1), 13-20. https://doi.org/10.1111/j.1467-8535.2004.00364.x

Beauchamp, G., \& Hillier, E. (2014). An Evaluation of iPad implementation across a network of primary schools in Cardiff. School of Education-Cardiff Metropolitan University. Retrieved July 16, 2016, from https://www.cardiffmet.ac.uk/education/research/Documents/iPadImplementation2014.pdf

Behera, S. K. (2013). E-and M-Learning: A comparative study. International Journal on New Trends in Education and Their Implications, 4(3), 65-78.

Bencheva, N. (2010). Learning styles and e-learning face-to-face to the traditional learning. Научни Трудове На Русенския Университеt, 49, 63-67.

Bogdan, R., \& Biklen, S. K. (2007). Qualitative Research for Education: An Introduction to Theories and Methods (5th ed.). New York: Pearson.

BrckaLorenz, A., Haeger, H., Nailos, J., \& Rabourn, K. (2013, May). Student perspectives on the importance and use of technology in learning. In Annual Forum of the Association for Institutional Research. Retrieved on May (Vol. 31).

Charmaz, K. (2011). Grounded theory methods in social justice research. The Sage Handbook of Qualitative Research, 4, 359-380.

Chen, G. D., Chang, C. K., \& Wang, C. Y. (2008). Ubiquitous learning website: Scaffold learners by mobile devices with information-aware techniques. Computers \& Education, 50(1), 77-90. https://doi.org/10.1016/j.compedu.2006.03.004

Colin, L. (2014). Open and Distance Learning Quality Assurance in Commonwealth Universities: A Report and Recommendations for QA and Accreditation Agencies and Higher Education Institutions. London: Commonwealth of Learning (COL).

Conrad, C. F. (1978). A grounded theory of academic change. Sociology of Education, 101-112. https://doi.org/10.2307/2112242

Crescente, M. L., \& Lee, D. (2011). Critical issues of m-learning: design models, adoption processes, and future trends. Journal of the Chinese Institute of Industrial Engineers, 28(2), 111-123. https://doi.org/10.1080/10170669.2010.548856

Creswell, J. W. (2003). Research design: Qualitative, quantitative, and mixed methods design. London: Sage.

Creswell, J. W. (2007). Five qualitative approaches to inquiry. Qualitative inquiry and research design: Choosing among five approaches, 2, 53-80.

Deegan, R., \& Rothwell, P. (2010). A classification of m-learning applications from a usability perspective. Journal of the Research Center for Educational Technology, 6(1), 16-27.

El-Hussein, M. O. M., \& Cronje, J.C. (2010). Defining Mobile Learning in the Higher Education Landscape. Educational Technology \& Society, 13(3), 12-21.

Gasparini, A., \& Culen, A. (2013). The iPad in a classroom: A cool personal item or simply an educational tool? ACHI 2013: The Sixth International Conference on Advances in Computer-Human Interactions, 204-209.

Geertz, C. (1973). The interpretation of cultures: Selected essays (Vol. 5019). Basic books.

Gogno, N. (2014). Advantages and Disadvantages of Online Testing. Retrieved July 28, 2016, from http://wp.lasalle.edu/blog/advantages-and-disadvantages-of-online-testing/

Hahn, J., \& Bussell, H. (2012). Curricular use of the iPad 2 by a first-year undergraduate learning community. Library Technology Reports, 48(8), 42-47.

Hamm, S., Saltsman, G. J., Baldridge, S., \& Perkins, S. (2013). A mobile pedagogy approach for transforming learners and faculty. Handbook of mobile learning, 176-186.

Henson, K. T. (2003). Foundations for learner-centered education: A knowledge base. Education, 124(1), 5.

Hockly, N. (2013, Mobile learning. ELT Journal, 67(1), 80-84. https://doi.org/10.1093/elt/ccs064

Karsenti, T., \& Fievez, A. (2013). The iPad in education: uses, benefits, and challenges-A survey of 6,057 students and 302 teachers in Quebec, Canada. Montreal, QC: CRIFPE. 
Keegan, D. (2005). Mobile learning: the next generation of learning. Distance Education International, 137-143.

Kemp, A. T., Preston, J., Page, C. S., Harper, R., Dillard, B., Flynn, J., \& Yamaguchi, M. (2014). Technology and teaching: A conversation among faculty regarding the pros and cons of technology. The Qualitative Report, 19(3), $1-10$.

Khaddage, F., Christensen, R., Lai, W., Knezek, G., Norris, C., \& Soloway, E. (2015). A model driven framework to address challenges in a mobile learning environment. Education and Information Technologies, 20(4), 625-640. https://doi.org/10.1007/s10639-015-9400-x

Khaddage, F., Müller, W., \& Flintoff, K. (2016). Advancing mobile learning in formal and informal settings via Mobile App Technology: where to from here, and how? Educational Technology \& Society, 19(3), 16-27.

Khechine, H., Lakhal, S., \& Pascot, D. (2013). University Students' Perception of the Pedagogical Use of Podcasts: A Case Study of an Online Information System Course. Journal of Education and Training Studies, 1(2), 136-151. https://doi.org/10.11114/jets.v1i2.139

Kim, D., Rueckert, D., Kim, D. J., \& Seo, D. (2013). Students' perceptions and experiences of mobile learning. Language Learning \& Technology, 17(3), 52-73.

Knezek, G., \& Khaddage, F. (2012). Bridging formal and informal learning: A mobile learning attitude scale for higher education. British journal of social sciences, 1(2), 101-116.

Kukulska-Hulme, A. (2009). Will mobile learning change language learning? ReCALL, 21(02), 157-165. https://doi.org/10.1017/S0958344009000202

Liaw, S. S., Hatala, M., \& Huang, H. M. (2010). Investigating acceptance toward mobile learning to assist individual knowledge management: based on activity theory approach. Computers \& Education, 54(2), 446-454. https://doi.org/10.1016/j.compedu.2009.08.029

Liu, H., Huang, R., Salomaa, J., \& Ma, D. (2008). An activity-oriented design framework for mobile learning experience. In Wireless, Mobile, and Ubiquitous Technology in Education, 2008. WMUTE 2008. Fifth IEEE International Conference on (pp. 185-187). IEEE. https://doi.org/10.1109/WMUTE.2008.30

Liu, M., Navarrete, C. C., Maradiegue, E., \& Wivagg, J. (2014). Mobile learning and English language learners: A case study of using iPod touch as a teaching and learning tool. Journal of Interactive Learning Research, 25(3), 373-403.

MacLeod, C. (2015). iPads in the classroom: trials in a technical college in Qatar. Learning and Teaching in Higher Education: Gulf Perspectives, 12(1).

Mang, C. F., \& Wardley, L. J. (2012). Effective adoption of tablets in post-secondary education: Recommendations based on a trial of iPads in university classes. Journal of Information Technology Education, 11(1), 301-317. https://doi.org/10.28945/1720

Mango, O. (2015). iPad use and student engagement in the classroom. Turkish Online Journal of Educational Technology-TOJET, 14(1), 53-57.

Mcconatha, D., Praul, M., \& Lynch, M. J. (2008). Mobile learning in higher education: An empirical assessment of a new educational tool. TOJET: the Turkish online journal of educational technology, 7(3).

Mehdipour, Y., \& Zerehkafi, H. (2013). Mobile learning for education: Benefits and challenges. International Journal of Computational Engineering Research, 3(6), 93-101.

Miangah, T. M., \& Nezarat, A. (2012). Mobile-assisted language learning. International Journal of Distributed and Parallel Systems, 3(1), 309-319. https://doi.org/10.5121/ijdps.2012.3126

MOBIlearn., (2003). Guidelines for learning/teaching/tutoring in a mobile environment. MOBIlearn. October 2003. p. 6.

Murthy, D. (2008). Digital ethnography: An examination of the use of new technologies for social research. Sociology, 42(5), 837-855. https://doi.org/10.1177/0038038508094565

Nguyen, L., Barton, S. M., \& Nguyen, L. T. (2015). Ipads in higher education-hype and hope. British Journal of Educational Technology, 46(1), 190-203. https://doi.org/10.1111/bjet.12137

Nordin, N., Embi, M. A., \& Yunus, M. M. (2010). Mobile learning framework for lifelong learning. Procedia-Social and Behavioral Sciences, 7, 130-138. https://doi.org/10.1016/j.sbspro.2010.10.019 
Ongori, H., \& Migiro, S. O. (2010). Information and communication technologies adoption in SMEs: literature review. Journal of Chinese Entrepreneurship, 2(1), 93-104. https://doi.org/10.1108/17561391011019041

Ozdamli, F. (2012). Pedagogical framework of m-learning. Procedia-Social and Behavioral Sciences, 31, 927-931. https://doi.org/10.1016/j.sbspro.2011.12.171

Quillen, I. (2011). Educators evaluate learning benefits of iPad. Education week, 4(3), 38-40.

Roden, K. (2011). Technology in Education. Online Submission. Retrieved July 17, 2016, from http://files.eric.ed.gov/fulltext/ED522014.pdf

Rossman, G. B., \& Rallis, S. F. (2011). Learning in the field: An introduction to qualitative research. Thousand Oaks, CA: Sage.

Rueckert, D., Kim, D. J., \& Seo, D. (2013). Students' perceptions and experiences of mobile learning. Announcements \& Call for Papers, 52-62.

Sanderson, M., \& Croft, W. B. (2012). The history of information retrieval research. Proceedings of the IEEE, 100 (Special Centennial Issue), 1444-1451. https://doi.org/10.1109/JPROC.2012.2189916

Santos, I. M., \& Bocheco, O. (2014). Mobile devices in the classroom: Emirati students' perceptions of usage and policies. In Interactive Collaborative Learning (ICL), 2014 International Conference on (pp. 956-962). IEEE. https://doi.org/10.1109/ICL.2014.7017905

Sarrab, M., Elgamel, L., \& Aldabbas, H. (2012). Mobile learning (m-learning) and educational environments. International journal of distributed and parallel systems, 3(4), 31-40. https://doi.org/10.5121/ijdps.2012.3404

Saxena, S. (2008). Using Technology in Education: Does It Improve Anything? Retrieved July 27, 2016, from http://edtechreview.in/news/681-technology-in-education

Selwyn, N. (2007). The use of computer technology in university teaching and learning: a critical perspective. Journal of computer assisted learning, 23(2), 83-94. https://doi.org/10.1111/j.1365-2729.2006.00204.x

Sharples, M., Taylor, J., \& Vavoula, G. (2005). Towards a theory of mobile learning. In Proceedings of mLearn (Vol. 1, No. 1, pp. 1-9).

Sharples, M., Taylor, J., \& Vavoula, G. (2010). A theory of learning for the mobile age. In Medienbildung in neuen Kulturräumen (pp. 87-99). VS Verlag für Sozialwissenschaften. https://doi.org/10.1007/978-3-531-92133-4_6

Singh, M. (2010). M-learning: A New Approach to Learn Better. International Journal of Education \& Allied Sciences, 2(2).

Sneller, J. (2007, October). The Tablet PC classroom: Erasing borders, stimulating activity, enhancing communication. In Frontiers In Education Conference-Global Engineering: Knowledge Without Borders, Opportunities Without Passports, 2007. FIE'07. 37th Annual (pp. S3J-5). IEEE.

Sword W. (1999). Accounting for presence of self: reflections on doing qualitative research. Qualitative Health Research 9(2), 270-278. https://doi.org/10.1177/104973299129121839

Teo, T. (2012). Examining the intention to use technology among pre-service teachers: an integration of the technology acceptance model and theory of planned behavior. Interactive Learning Environments, 20(1), 3-18. https://doi.org/10.1080/10494821003714632

Traxler, J. (2007). Defining, Discussing and Evaluating Mobile Learning: The moving finger writes and having writ.... The International Review of Research in Open and Distributed Learning, 8(2). https://doi.org/10.19173/irrodl.v8i2.346

Velev, D. G. (2014). Challenges and opportunities of cloud-based mobile learning. International Journal of Information and Education Technology, 4(1), 49. https://doi.org/10.7763/IJIET.2014.V4.367

Yang, C. C., \& Wang, F. L. (2003). Fractal summarization for mobile devices to access large documents on the web. In Proceedings of the 12th international conference on World Wide Web (pp. 215-224). ACM. https://doi.org/10.1145/775152.775183 